\title{
Refugee-Host Interactions: A Field Report from the Ukwimi Mozambican Refugee Settlement, Zambia
}

\author{
Véronique Lassailly-Jacob
}

\section{Mozambican Refugees in Neighbouring Countries}

As a result of the civil war which has been raging in Mozambique for 16 years, an estimated 1.7 million Mozambican people have sought refuge in neighbouring countries and more than 3.5 million have been internally displaced (World Refugee Survey 1993:67). At present, Mozambique has the largest registered refugee population on the African continent. By the end of 1992, 1.1 million Mozambicans had found asylum in Malawi, more than 300,000 in South Africa ${ }^{1}$ and the KaNgwane, Gazankulu, Lebowa and KwaZulu homelands, about 264,000 in Zimbabwe, 72,000 in Tanzania, 25,000 in Zambia and 20,000 in Swaziland (ibid.). Local integration in the country of first asylum has been the only durable solution for these longterm refugees, most of them having a rural background. Rural refugees either spontaneously settle in border areas or are channelled towards assigned areas where they are regrouped, registered and assisted.

Self-settled Mozambican refugees are found in border areas in Zambia, Tanzania, Malawi, Swaziland and Zimbabwe. According to World Refugee Survey (1993), up to 130,000 Mozambicans have settled spontaneously in the Zimbabwean countryside. They are also found in the homelands of Gazankulu, KaNgwane, Lebowa and Kwazulu. Self-settled refugees create small villages or settle among the local population. They manage to integrate and survive with the assistance of local people, by gaining land from local chiefs, trading or by obtaining agricultural wage labour. They

Veronique Lassailly-Jacob from France is a visiting scholar at CRS, York University. form the hidden majority of Mozambican refugees and African refugees in general: "hidden" because host governments try to avoid this uncontrolled kind of settlement for security and political reasons. On the one hand, host governments need statistics about the number of refugees entering into their territory in order to satisfy requirements for international assistance, while on the other hand, they are afraid of insecurity erupting along their borders. In 1987, RENAMO carried out cross border raids against refugees in Zambia and Zimbabwe, killing or kidnapping refugees and local people. For these reasons, host governments usually decide to regroup refugees in camps or agricultural settlements away from the border. By law, all refugees entering Zambia must declare themselves to the police and be taken to a transit camp or an organized settlement.

Assigned areas are divided into reception or transit centres, "care and maintenance camps" (Callamard, this issue) and agricultural settlements. Refugees do not have access to adequate farmland for crop production (except some vegetable gardens) and survive mainly on food supplied by the World Food Program. They are heavily dependent upon aid agencies for all of their basic day-to-day needs and develop a "dependency syndrome."

Agricultural settlements appeared in Africa as a form of UNHCR assistance in the early 1960s. These represent the other type of organized settlement for refugees. Based on the model of land settlement schemes, they are supposed to promote refugee self-sufficiency and local integration. Scheme-settled refugees receive plots of arable land, tools and seeds which enable them to become self-reliant.
Agricultural settlements have received considerable attention and funding from the international community and many local and international NGOs. Host countries provide the agricultural land and administrative services to run these settlements. Today, three agricultural settlements are still operating for Mozambican refugees; Likuyu in Tanzania, Ndzevane in Swaziland, and Ukwimi in Petauke district, Zambia.

\section{Ukwimi Mozambican Refugee Settlement}

Ukwimi is an agricultural settlement established in 1987 in the Eastern province of Zambia, $70 \mathrm{~km}$ north of Petauke and more than $100 \mathrm{~km}$ from the border. Refugees receive relief assistance in addition to 2 hectares of arable land, tools, seeds and other agricultural inputs in order to become self-sufficient. Ukwimi was first established to regroup the Mozambican refugees who had spontaneously settled in the border area following the 1987 RENAMO raids. At that time, new waves of refugees were arriving in Ukwimi, fleeing the warbut also driven by drought and famine. The last refugees arrived in March 1993. At the time of research (summer 1993), there were 25,600 refugees settled in 73 "villages" scattered over 310 square $\mathrm{km}$. Most refugees at Ukwimi are peasant farmers coming from the Zambia-Mozambique border area and from northern Tete Province.

Ukwimi was implemented under a tripartite agreement between $\mathrm{UNHCR}$, the government of the Republic of Zambia and Lutheran World Federation (LWF). In addition, several other implementing partners have been operating in Ukwimi. This settlement is carefully planned and managed. It is organized in two headquarters (Ukwimi A and B), each of them super- 
vising a number of satellites, (four satellites under Ukwimi $A$, three satellites under Ukwimi B), that in turn serve 10 to 12 refugee villages each. Refugees benefit from extensive infrastructural investment and development assistance, including seven primary schools, clinics, good roads, clean water, markets, shops, grinding mills, warehouses, farming programs, income-generating activities, skilltraining programs, community services, poultry farms and piggeries.

The two communities are related to each other. Both local Zambians and a large number of the refugees belong to the Chewa and Nsenga ethnic groups. They speak the same language and share a common culture and set of traditions. Seven Zambian villages were already settled inside the settlement boundaries when the first refugees arrived in Ukwimi in 1987. Their population was estimated at 1,000 people (Black et al. 1992). The authorities decided not to remove them but to include them in the settlement programs.

Each Zambian village was given a demarcated territory including its own fields and was not allowed to cultivate areas outside of these new boundaries as it had in the past. Today, there are nine Zambian villages and five "hamlets" inside the refugee settlement boundaries. Two additional Zambian villages moved from outside the settlement boundaries and reclaimed traditional lands within the settlement boundaries. The movement of Zambian villages into the refugee settlement was motivated by a fear of losing access to traditional lands through the expansion of agriculture by the growing refugee population on the one hand, and the attraction of the newly constructed infrastructure of the settlement on the other hand. As for the Zambian "hamlets", they were mainly established by city leavers who had acquaintances in the surrounding villages. Although there were no available statistics concerning the number of local Zambians presently living inside the settlement, I estimated that there were well over one thousand.
Both Chambers (1986) and Hansen (1990) note that local people benefit from refugees' presence because refugees provide a market and a supply of cheap labour. Refugees are therefore resources for the economic growth and development of the host districts. As far as the self-settlement option is concerned, only two partners interact, refugees and their hosts. In the case of the scheme-settlement option, another important partner has to be added, the planners. They play a major role in planning and designing the site, reallocating natural resources, distributing assistance and introducing infrastructural services, farming programs, income-generating activities, skill-training programs, community services, etc. Interactions between scheme-settled refugees and their hosts cannot be understood without observing planners' actions.

\section{Purpose of My Research}

This past summer (1993), I spent a month in Ukwimi and conducted interviews with randomly selected men and women, mainly local Zambians (25) but also refugees (6), agency workers and local government officials (10). The main objectives of my study were to analyze the impact of the refugee settlement on the local people as well as the interactions which developed between refugees and their hosts. First, I tried to understand what was the situation of the area in terms of local economic activities, ecology and infrastructure prior to the refugee settlement. Then, I considered the changes brought about in the local population's way of life as a result of the refugee settlement.

In addition, I analyzed refugee-host interactions, asking questions about social relationship, land tenure, labour, bartered or marketed produce and other economic exchanges. Finally, a last set of questions helped me to understand how the local people perceived their future when the refugees returned to Mozambique. This brief field report will only mention some comments about host-refugee interactions and assistance.

\section{Some Comments on Host-Refugee Interactions}

"Relish" supplements the maize porridge called nsima which is the main course of the two daily meals. Relish is an important part of traditional meals and it improves the nutritional quality and variety of the diet. It can consist of edible leaves, vegetables, mushrooms, fruit, meat, fish, honey, insects, rodents, caterpillars, or tubers, etc. "Bush foods," or wild resources, represent the main sources of relish which are also partly cultivated on farmlands.

Before the refugees arrived, the local people used to hunt, fish and gather these bush foods. These products were used for both home consumption and marketing. Local people also used to grow pumpkins, beans, okra, sweet potatoes and cassava in their upland fields, and collect edible leaves for making relish. From the fruit trees growing in their villages, they ate or traded mangos, papayas, guavas, and bananas, in addition to rearing small livestock such as chicken, goats and pigs. A few households also had small dry-season gardens in valley areas where they grew bananas, sugar cane and some vegetables. However, these gardens could not be extended because of the abundant wildlife (elephants, monkeys or bush pigs) which often destroyed crops that were not adequately guarded.

Upon arrival, refugees were given food rations and a "food basket" consisting of maize, beans, cooking oil, salt and sugar which was distributed to each household for the following two years. Refugees typically tried to diversify this monotonous diet by using what I call three "food research strategies." The first consisted of collecting relish from the natural environment. The most populated areas inside the settlement rapidly suffered from the depletion of these natural resources.

Resource competition and the resultant shortage of gathered products has affected Zambian incomes through reducing the availability of these products for sale and has generally had negative impact on diet 
and general wellbeing (Sullivan 1992:20).

As a consequence, local people now travel far outside of the settlement to collect bush foods. Collecting wild resources, usually a female-dominated activity (except collecting honey and hunting) is now a male-dominated activity because of the long walking distance involved. Local women have lost this traditional source of income.

Bush fires were traditionally set in August when all crops had been harvested and stored and wild grass had been collected for thatching. Now, refugees set bush fires early in June or July in order to catch rodents. These early bush fires threaten the local population's maize which remains in the fields until transport is available. In contrast, refugee maize is collected very early because refugee villages have been provided with ox-carts by LWF. Depletion of wild resources and the premature setting of bush fires by refugees has led to bitterness and resentment from the local population. Local Zambians accuse the refugees of improperly managing the environment.

They chop down the trees we worship, they chop down very old trees along the streams in order to extend their garden when these trees helped prevent evaporation with their shade. They collect all the bamboo and reeds at one place, they use chemicals to kill fish and wash their clothes in the stream, polluting the water we drink, they light bush fires too early to hunt mice and rats when our maize is still in the fields. (Local Zambian in Ukwimi settlement).

In other words, they behave as outsiders who do not manage an environment that does not belong to them.

The second "food research strategy" consisted of getting relish from the local Zambians by barter or labour exchange. Refugees exchanged cooking oil, salt, clothes and shoes for sweet potatoes, green vegetables, chicken and fruit. Piecework for Zambians included digging and weeding in exchange for food items. Refugee girls often pound or shell maize for Zambian women in exchange for mangos or other fruits. As a result, many Zambians, mainly the wealthier people who could afford paid labour, were able to extend their upland farms by using refugee labour.

The third "food research strategy" consisted of growing foods on available farmland. In addition to their upland farms, refugees looked for extra land to cultivate and developed dry season vegetable gardening in valley areas called dambo land. Many refugees asked permission from the Zambian people to have a garden plot. While refugees have been given plots as well as seeds and fertilizers for free or in exchange for a proportion of the subsequent harvest, local people were not included in the distribution of agricultural inputs. As a result, local people are very resentful of having to buy vegetables grown on their own land by refugees who are highly assisted. Increasingly, there are disputes between refugees and Zambians over dambo land, particularly in the northern part of the settlement where the refugee population density is high.

\section{Some Comments About Assistance and the 1991-92 Drought}

In theory, after two years, refugees are supposed to be self-sufficient and at that time are cut off from food and agricultural assistance. In practise however, refugees are cut off from food assistance but not from agricultural inputs and support. Refugees continue to receive agricultural inputs like fertilizers and seeds on a credit basis indefinitely. Local people were complaining in these terms:

We understand that refugees had nothing when they arrived here and they should be helped and assisted and we agreed to give them land to feed them. But we see that now many refugees make a lot of profit from our land. They are now growing tobacco, cotton, sunflowers, vegetables and they are provided with seeds and fertilizers when we get nothing.

After two years, refugees are still refugees, having free access to medical care (free hospital fees) and schools (free uniforms, free boarding fees, free ex- amination fees) while local people have to pay.

The 1991-92 drought disrupted this policy of refugee assistance and highlighted the disparities between the local and refugee population. In the Ukwimi area, the drought was not due to inadequate rainfall but to the lack of rain in the critical months of January and February. When the rains resumed in March, it was too late to save the crops. Hosts and refugees were equally affected by this terrible drought.

The drought response program was not the same for refugees and local people, however. Refugees received maize, beans, fertilizers and groundnut seeds (on loans), and drought-resistant seeds like sorghum and cassava sticks, while the Zambian people received only maize. Some of the poorer Zambians actually went to work on the refugee fields to get groundnut seeds for the next season.

\section{Conclusion}

Economic differentiation between households is broader in the refugee community than in the Zambian community. A number of refugees were very successful as farmers or woodcarvers and invested their profits in shops and grinding mills. All private shops and grinding mills in the settlement were owned by refugees, and in addition it was observed that many refugees had bicycles, watches, and radios. Despite the fact that some refugees have a higher income than the local Zambians, they continued to be assisted because of their refugee status, while the local population remained unassisted.

Undoubtedly, the host community benefits from the improved infrastructure and services but those who benefit the most are the headmen and the already wealthy people and those who live near the settlement's headquarters. Being in charge of distributing farmland, headmen offer land to refugees and staff people. In return, they receive many presents as a token of appreciation. Those who live near the

Continued on page 23 


\section{CENTRE FOR REFUGEE STUDIES \\ Annual Dinner and Meeting \\ Jade Garden Restaurant}

\section{Spadina Avenue, Toronto \\ February 17, $1994 \cdot 6: 30$ p.m.}

\section{DONOR INFORMATION}

Corporate Patron

A table for ten to the dinner

plus a subscription to Refuge and notification

of events sponsored by the Centre

Patron

One ticket for the dinner

plus a subscription to Refuge and notification

of events sponsored by the Centre

Friend

One ticket to the dinner

$\$ 600$

Special student rate

$\$ 125$

\section{REGISTRATION FORM}

I would like to reserve table(s). Total number of dinner tickets required:

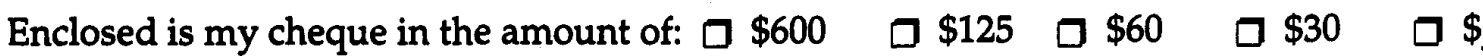

(Financial subsidies are available for eligible attendees. Please enquire.)

$\checkmark$ I will attend the dinner

$\square$ I can not attend the dinner on February 17, 1994

Menu preference: $\square$ Regular $\square$ Vegetarian

Method of payment: $\square$ Cheque. Please make cheque payable to: Centre for Refugee Studies

Charge to my:

$\square$ Visa

MasterCard

Amex

Please print information below

Card number Expiry Date:

Card holder's name:

Signature:

Please send official tax receipts, correspondence, publications and dinner tickets to:

Name

Organization

Address

City

Postal Code

Tel: Fax:

Please send or fax your completed form to:

Helen Gross, Centre for Refugee Studies

Suite 322, York Lanes, York University

4700 Keele Street, North York, ON M3J 1P3

Fax: (416) 736-5837 - Tel: (416) 736-5663

Refuge, Vol. 13, No. 6 (October 1993) 


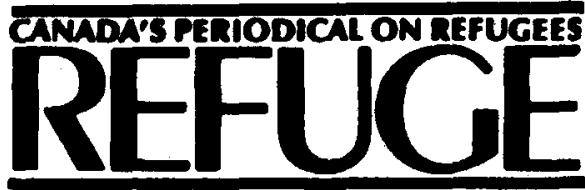

Refuge

York Lanes Press

Centre for Refugee Studie:

Suite 351, York Lanes, York Univernity

4700 Keele Street, North York

Ontario, Canada M3J 1P3

Phone: (416) 736-5843 - Fax: (416) 736-5837

Electronic Mail via Bitnet Address:

REFUGE QYORKVM1

Postage Paid in Toronto, Canada

Second Class Mail Registration No. 5512

Return Postage Guaranteed

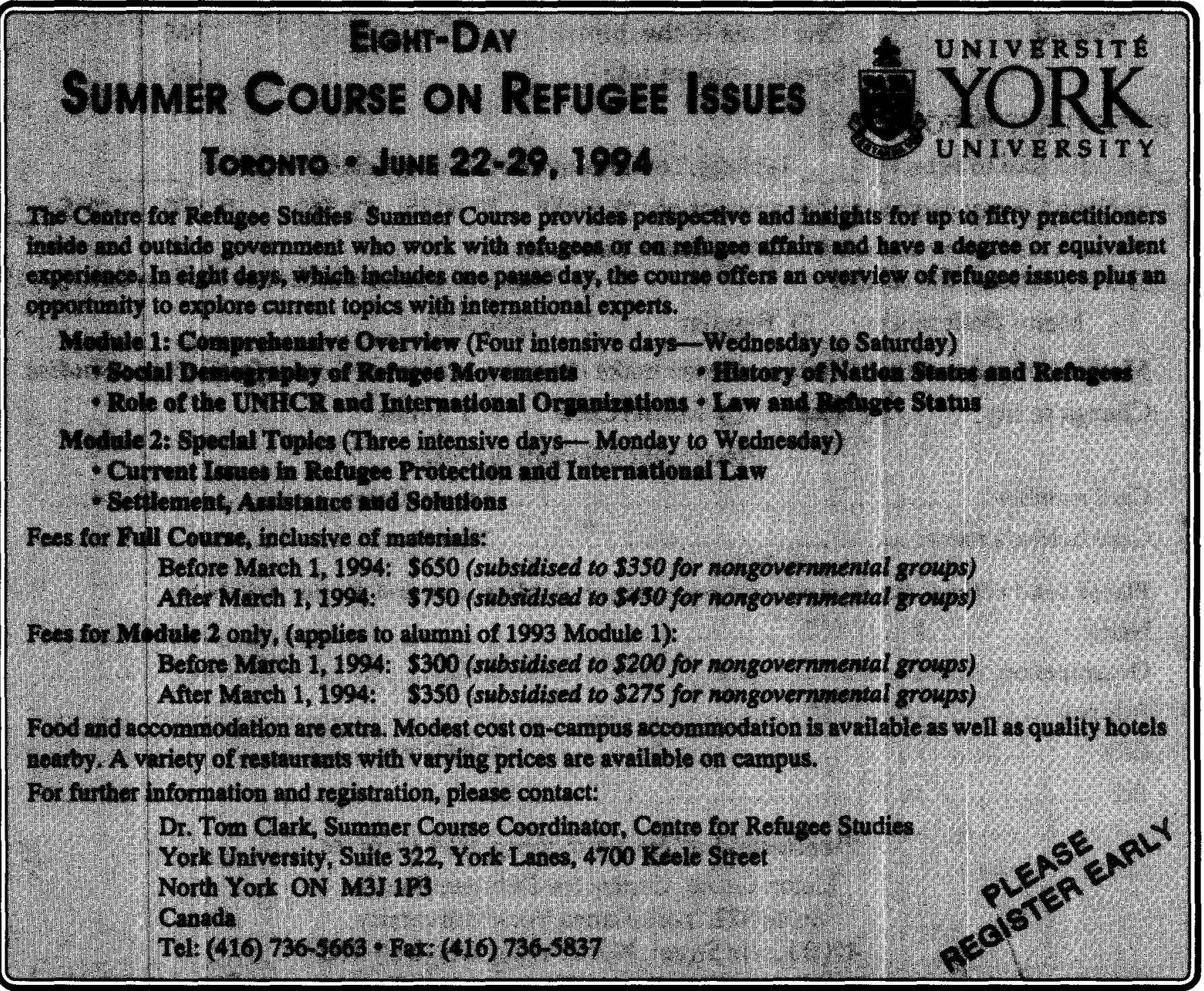

